\title{
Using social media in writing among Primary School pupils
}

\author{
Aderlin Chung Kim Yuk* \\ Sekolah Jenis Kebangsaan Foon Yew 1 - Malaysia \\ yuky92@gmail.com \\ Melor Md Yunus ${ }^{* *}$ \\ Universiti Kebangsaan Malaysia - Malaysia \\ melor@ukm.edu.my \\ Ashairi Suliman ${ }^{* * *}$ \\ Universiti Kebangsaan Malaysia - Malaysia \\ ash860629@yahoo.com
}

\begin{abstract}
The advancement of technology has brought transformation in education. Utilisation of social media to promote learning are increasing exponentially at secondary and tertiary education levels. However, the researcher was still doubting using social media on current primary school pupils. Thus, this study aimed to explore the use of social media among primary school pupils and how they perceive towards the use of English in writing on social media. Questionnaires were distributed among 37 primary 4 pupils in a Chinese vernacular school in a Southern state in Malaysia. The findings showed that YouTube is the most prominent tool used among the pupils and they have good competency in using the social media which they always use. Pupils use social media for academically and non-academically purposes. However, slightly more than half of the pupils do not have positive perceptions towards using English in writing on social media. Social media could be exploited in learning writing activities to increase the awareness of pupils towards a better writing performance.
\end{abstract}

Keywords: social media, English language, primary pupils, ICT, education.

\section{RESUMEN}

El avance de la tecnología ha traído transformación en la educación. La utilización de las redes sociales para promover el aprendizaje está aumentando exponencialmente en los niveles de educación secundaria y terciaria. Sin embargo, el investigador todavía dudaba de usar las redes sociales en los alumnos actuales de primaria. Por lo tanto, este estudio tuvo como objetivo explorar el uso de las redes sociales entre los alumnos de primaria y cómo perciben el uso del inglés en la escritura en las redes sociales. Los cuestionarios se distribuyeron entre 37 alumnos de primaria 4 en una escuela vernácula china en un estado del sur de Malasia. Los resultados mostraron que YouTube es la herramienta más destacada utilizada entre los alumnos y que tienen una buena competencia en el uso de las redes sociales que siempre usan. Los alumnos usan las redes sociales con fines académicos y no académicos. Sin embargo, un poco más de la mitad de los alumnos no tienen percepciones positivas sobre el uso del inglés por escrito en las redes sociales. Las redes sociales podrían explotarse en el aprendizaje de actividades de escritura para aumentar la conciencia de los alumnos hacia un mejor rendimiento de escritura.

Palabras clave: redes sociales, idioma inglés, alumnos de primaria, TIC, educación.

\footnotetext{
* Sekolah Jenis Kebangsaan Foon Yew 1, 80250 Johor Bahru, Johor, Malaysia.

${ }^{* *}$ Corresponding author. Faculty of Education, Universiti Kebangsaan Malaysia, 43600 Bangi, Selangor, Malaysia

*** Universiti Kebangsaan Malaysia, 43600 Bangi, Selangor, Malaysia
}

Recibido: 22/09/2019 Aceptado: 05/11/2019 


\section{INTRODUCTION}

Social media (SM) is growing exponentially and becomes ubiquitous nowa-days. Social media are Web 2.0 Internet-based applications which promote the development of social networks online by connecting a profile with other individuals and groups (Obar \& Wildman, 2015). It is also known as social networking sites (Facebook and Twitter), blogging sites (WordPress) and other sites (YouTube) that provide the chance for collaboration, socialization and production of works. Social media stresses the social aspects in the form of communication, collaborative learning and inventive expression (Won, Burton, Evans, Baum-Walker, \& Grafsky, 2015). Due to the social aspects featured in the social media, many educators viewed social media as an educational site in which teachers can truly access the learning potential of their students through proper designation of learning activities.

The fact that social media is an attraction to students as they are a mean for students to self-express and interact with each other. It is also the platform that gives a motivating vibe in learning (Abdullah, Hashim, \& Mahmud, 2018). This is because social media offers the features of streaming, posting, photo sharing and video sharing. However, the author of the current study was still hesitating to choose a social media in teaching and practicing writing skills. Writing skill is one of the four major language skills need to be learnt by language learners at any level. In the current school context, it is hard to engage pupils in writing due to insufficient motivation, anxieties, afraid of committing errors or lack of idea to produce a good writing (Alfian, 2017). This goes in line with (Harmer, 2004) that their struggling in writing may derive from their anxieties in their handwriting, their spelling or their potential to make sentences and paragraphs. A way of provoking student engagement with writing is to encourage them to write to each other (Harmer 2007) and this could be done by employing social media as writing platform.

As the context of this study is at primary school, it is important for the re-searcher to begin with knowing pupils' preferences of social media in learning and their learning pattern before choosing the right tool. Students are ought to be given meticulous scrutiny to investigate their utilisation of the tools they are comfortable and familiar with and which they feel feasible in completing writing tasks (Tay \& Allen, 2011).

Therefore, this present preliminary study was conducted to achieve the following objectives:

- To investigate the access of ICT tools among the respondents.

- To identify how often the respondents use SM.

- To identify respondents' competency in SM and its relationship with the frequency use of SM

- To investigate factors affecting the Use of SM and factors contributing to the use of SM across Gender

- To investigate the use of English in writing on SM among the respond-ents.

2.

\section{LITERATURE REVIEW}

\section{Influence of social media}

With the support given by Information, Communication and Technologies (ICT) and hardware in the current available handheld devices, social media can be accessed conveniently, enabling its users to be connected without the restriction of place and time (Yunus et al., 2010; Nordin, et al. 2010). The Utilization of ICT in the Teaching and Learning of English: 'Tell Me More'. Procedia. Social and Behavioural Sciences, 9, 685-691. https://doi.org/10.1016/j.sbspro.2010.12.218. The young generations are easily influenced by technologies. According to the report from a digital strategist, social media like Facebook, YouTube, WhatsApp and Instagram are predominantly favourable platform among the young generations, most of whom are students and adolescents (Chaffey, 2019). Currently, Facebook is the largest social networking which boast over 2.2 billion users worldwide (Abdurahman, Hassan, Sayuti, \& Abdullah, 2019; Chaffey, 2019) while YouTube is regarded as the most frequently used social media among students (Jumaat et al., 2019; Muyingo, 2017).

Students nowadays are growing up at the era when technology has advanced to an extent that the utilisation of the Internet is a daily life affair. They are bounded through social media apps to interact with each other or disseminate information, knowledge and interest which can increase efficiency in individual and group assignment (Abdurahman et al., 2019). In education, social media has gradually been used to promote teaching and learning activities. With the advancement of technology, students can now relish the joy of learning beyond the four walls. It is believed that enjoyment is a contributor to educational outcomes. Past studies (Nov, Naaman, \& Ye, 2010; Zolkepli \& Kamarulzaman, 2015) found that enjoyment stimulates their intrinsic motivation to share photos and engage in virtual discussion. They are inadvertently learning and creating language through their conversation in social media.

The popularity of social media sites has motivated social communication and engagement at an unprecedented scale. These encompass improving relationship, enhancing motivation in learning, offering personalized course material, and reinforcing collaboration (Shiva, Fahimeh, \& Ghani, 2016). This means that social networking activities have the possibility of transforming passive individuals into active learners as they participate in virtual group learning, with less apprehension to raise questions at school (Nov et al., 2010).

Also, social media is found to enhance Learning Management System (LMS). LMS such as Edmodo, Moodle and Open Learning integrate integrates features of social media, including instant chat functions, videos, forums to share information and other lesson resources to help students and teachers. The integration of LMS based on social media and network platform helps to create different kind of communication and channel motivation, interest and 'real life' to formal study (Anderson \& Dron, 2017). 


\section{Students' Motives for Using Social Media}

Interpersonal interaction, passing time, obtaining information, convenience, and leisure were identified by scholars as reasons for using the Internet (Jiyoung Cha, 2010; Liu, Zhang, Ye, \& Liu, 2018; Papacharissi \& Rubin, 2000). Previous studies on the advantages of social media showed that students have the need to maintain social relationship with former classmates, communities and families when they are away from them (Özad \& Kutolu, 2010; Shabir, G., Yousef, M., Yousef, H., Safdar, G., Farouq, 2014; Zolkepli \& Kamarulzaman, 2015). Some students take social media as a platform to escape from their daily routines and problems and to kill boredom. Information seeking is also prevalent among students, whether for the purpose of homework or assignment. They are motivated to utilise social networking because of the feature of interactivity which ensures them to engage in personal and group conversation (Rdouan Faizi, El Afia, \& Chiheb, 2014) as well as to obtain instantaneous information (Zolkepli \& Kamarulzaman, 2015). Reading comments are regarded as seeking information (Lee \& Ma, 2012). Besides that, social media is perceived as being convenient and easy to use as it is now accessible through most electronic gadgets such as iPhone, android phone, iPad/tablet and computers. In addition, it allows synchronization too. Entertainment is viewed as one of the personal needs for escapism and re-laxation (Khan, 2017). Through social media, students seek entertainment from various sources such as comments, videos, pictures and jokes which can be created by users or shared by other websites (Liu et al., 2018), and follow friends' profile, trends, artists and fashions. A finding which aims to unearths the motives of students for engaging in YouTube revealed that most of the students read comments for entertainment besides seeking information (Zolkepli \& Kamarulzaman, 2015) but did not write for the same purpose (Muyingo, 2017).

Some researchers found that there are statistically significant differences exist in social media usage by gender in which number of women users on social media compared to men were found (Gwena, Chinyamurindi, \& Marange, 2018; Khan, 2017). In this study, it also aims to investigate whether there is any significant difference in the factors contributing to the use of social media across the gender among primary school pupils.

\section{Integration of Social Media into ESL Writing Classroom}

With the increasing number of social media sites in existence and the increasing number of users, social media is undoubtedly influencing the writing of students (Saad, Yunus, Embi, \& Mohd Yasin, 2014). With the rapid evolvement of web technology and its effectiveness, a number of educators are delving deeper into incorporating social media in their teaching and learning process to develop pupils' learning abilities in writing skills. Without underestimating the role of traditional media, digital media is deemed to be more largely accepted by students (Fauzi, 2017). To ensure learners to be successful in writing skill, educators have to choose appropriate method, technique or media to assist pupils in learning.

Previous studies of integrating social media in ESL writing classroom has yielded positive results in learners' writing attitudes, for example, developing language awareness through collaborative writing on social media (Tay \& Allen, 2011), enhancing their writing motivation (Chandran, Plaindaren, Pavadai, \& Yunus, 2019) and building confidence in learning ESL writing (El-Sawy, 2015; Saad et al., 2014). The interactions among students through writing on social networking site has fostered cooperative and collaborative learning (Toetenel, 2014). In association to this, a higher quality of students' writing and critical peer feedback are observed based on a quasi-experimental study on using blog-mediated feedback (Novakovich, 2016). Moreover, tweeting has also contributed to the development of a new literacy practice, such as Twitteracy, which assist formal and informal learning (J. Li \& Greenhow, 2015).

When social media is incorporated in writing activities, it promotes two way of interactions among both teacherstudents and student-student. At school, students often write only for the teacher but when they know that they will be writing for a wider audience as it will be shared on the social media, they put in more efforts into writing (R Faizi, Afia, \& Chiheb, 2013; Rdouan Faizi et al., 2014). Therefore, this shows that social media has the potential to boost learners' motivation and self-worth towards writing.

Furthermore, using social media in writing classroom could inadvertently resolve the problems encountered by educators in providing timely feedback on students' composition. With proper guidance from the teacher, students can also give constructive feedback to their peers' writing (Yusof, Manan, \& Alias, 2012). This is also supported in another study which found that Google+ provides students with convenient and attractive features to engage them in knowledge sharing, giving feedback to correct others errors or add new ideas in others writing and review their own writing at their own pace (Mohammad, Ghazali, \& Hashim, 2018). When students post their writing on the social networking website, other students could also give feedback in the form of 'likes', 'emoticons' or short comments.

Besides that, not only the students who receive feedback would benefit but the students who give feedback would also learn to give critical response. Peer feedback through social media platform can consequently help a number of learners to be self-reliant so that they could self-edit their own work so that students can write better (Rollinson, 2005). Mervat Abd Elfatah Ali Said Ahmed (2016) also reported based on the quasi-experimental research on using Facebook grammar discussion and writing skills that students wrote better using more meaningful contents with well-organized and grammatically structured essay in the post-test. This is also in line with studies which discovered that social media-facilitated writing could help the students to be more conscious towards punctuations, spelling and grammar structures in writing (Akhiar, Mydin, \& Kasuma, 2017; El-Sawy, 2015; Hashim et al., 2018).

Social media could bridge the gap between formal learning in the classroom and informal learning outside the classroom (Mustapha, Rahman \& Yunus, 2010(a); Mustapha, Rahman \& Yunus, 2010(b)). Majid \& Stapa (2017) showed that scaffolding from teacher in the form of modelling, instruction, feedback and questioning based on the descriptive writing topic could be facilitated by Facebook on secondary level students. Students who had undergone 
the treatment of scaffolding through Face-book in accomplishing descriptive writing scored better in the post-test compared to the students who only received face-to-face scaffolding in the classroom.

Despite the advantages that social media brings, some disadvantages were found in the findings. It is true that social media can provide a platform for language interaction. However, participants could develop indifference to the technology. Some students failed to manage social media rightly as the time spent on social media is rather higher than time spent studying, compared to the non-user of social media (Abdurahman et al., 2019). Some students claimed that using social media does not contribute much in improving their grammar, vocabulary, spelling or other linguistic features (Hashim et al., 2018). Moreover, teachers also need to reconsider their roles as teacher in facilitating the use of social media effectively in education.

\section{METHODOLOGY}

In order to attain the purpose of this study, a total of 37 primary 4 pupils were selected by using non-probability of convenience sampling method from an urban Chinese vernacular school in one of the states in southern of Malaysia. The respondents for this study were chosen as most of them are coming from intermediate or above-intermediate social financial background status with experience of using social networking. Besides, their English proficiency level are of intermediate level and above intermediate level. As this study employed quantitative research design using survey, having these criteria allows them to have good understanding and experience in answering the questions in survey.

Under the supervision of the researcher, the respondents were first given explicit delivery of the aims of the research and were told to complete the questionnaire thoroughly according their own experiences of using SM. The participants were also informed that the result of the research is confidential and it will not do any harm to them. In order to keep their privacy, all the participants' names were concealed and would not be used in reporting the research. The participants should complete all the questions within 30 minutes with teachers' guidance.

The data collected from the questionnaire were analysed by using a statistical software, SPSS version 25 . There were five sections in the questionnaire, which were as follow:

- Section A consists of questions which aimed to identify access of ICT tools among the respondents.

- Section B consists of questions which aimed at eliciting information on how often the respondents use each listed social media.

- Section C consists of questions which aimed at eliciting information on how respondents perceive their own competency in using each social media.

- Section D consists of questions which aimed at eliciting information on factors affecting the use of social media among the respondents.

- Section E consists of questions which aimed at eliciting information on their perceptions towards the use of English in writing on social media.

\section{FINDINGS AND DISCUSSION}

\section{Demographic Profile of Respondents}

The participants consist of (40.5\%) male and (59.5\%) female. The frequency of the pupils starting to use social media is shown in Table 1.

Table 1. Demographic profile of respondents

\begin{tabular}{ccc}
\hline Gender & Male & $40.5 \%$ \\
& Female & $59.5 \%$ \\
\hline \multirow{2}{*}{ Experience in using SM } & $1-3$ years & $27.1 \%$ \\
& $4-6$ years & $37.8 \%$ \\
& $7-9$ years & $35.1 \%$ \\
\hline
\end{tabular}

From the statistics in Table 1, pupils started using social media as early as 1-3 year-old. More than half of the pupils (64.9\%) had the access to social media before they started entering elementary school at the age of 7 , indicating that most of them had at least 4 years' exposure to social media.

\subsection{Access to ICT tools}

Table 2. Number of pupils who have access to ICT tools

\begin{tabular}{ccc}
\hline Access & Yes \% & No \% \\
\hline Computer & 67.6 & 32.4 \\
Laptop & 97.3 & 2.7 \\
IPAD & 59.5 & 40.5 \\
Internet & 100 & 0 \\
Using Social Media & 100 & 0
\end{tabular}

Based on Table 2, among computer, smartphone and IPAD, smart phone is the most frequent tool accessed by the 
pupils. A great number of $97.3 \%$ pupils have access to smart phone while only $2.7 \%$ respondent does not have the access. This is followed by a number $67.6 \%$ pupils who have access to computer while $32.4 \%$ respondents do not have the access to computer. The least used tool is IPAD. However, more than half of them, $59.5 \%$ pupils have the access to IPAD while $40.5 \%$ respondents do not have the access to computer. From these data, it can be concluded that these pupils are not strange to technology tools as they have exposure to at least one of these tools. Besides that, all the 37 pupils reported they have access to Internet and they use social media. From the statistics, it is evident that all the pupils were indeed tech-savvy as they were familiar with either computer, smart phone, IPAD, Internet or social media.

\subsection{Frequency Use of Social Media (SM)}

Table 3. Frequency use of Social Media (SM)

\begin{tabular}{cccccc}
\hline & \multicolumn{2}{c}{ Number of respondents \% } \\
Social Media & Never & Seldom & Sometimes & Always & Mean score \\
\cline { 2 - 5 } & & & & 62.2 & 3.59 \\
YouTube & 0 & 2.7 & 35.1 & 45.9 & 2.97 \\
Whatsapp & 13.5 & 21.6 & 18.9 & 2.7 & 2.00 \\
Facebook & 35.1 & 32.4 & 29.7 & 10.8 & 1.84 \\
Tik Tok & 48.6 & 29.7 & 10.8 & 5.4 & 1.73 \\
Wechat & 48.6 & 35.1 & 10.8 & 13.5 & 1.59 \\
Instagram & 70.3 & 13.5 & 2.7 & 2.7 & 1.57 \\
Snapchat & 62.2 & 21.6 & 13.5 & 2.7 & 1.35 \\
LINE & 75.7 & 16.2 & 5.4 & 0 & 1.05 \\
Twitter & 97.3 & 0 & 2.7 & 0 & 1.03 \\
Telegram & 97.3 & 2.7 & 0 & & \\
\hline
\end{tabular}

Rating from 'Always' to 'Never' ranged from 1-4 (mid-point is 2.5)

In this section of the questionnaire, the frequency of using of SM ranged from 1-4, 1 indicated 'never', 2 indicated 'seldom', 3 indicated 'sometimes' and 4 indicated 'always'. The SM applications were arranged from the most often used to the least used based the mean obtained. By analysing the mean of the frequency use of SM in Table 3, it can be seen that YouTube, WhatsApp and Facebook were the three most favourable SM application used by the pupils. The result of YouTube application showed the highest mean value $(\mathrm{M}=3.59)$, with more than half of the respondents $(62.2 \%)$ who always use YouTube and none of them claimed that they had never use YouTube. This is followed by WhatsApp $(M=2.97)$, the $S M$ with the second highest number of frequent users and Facebook $(M=2.00)$, the $S M$ with the third highest number of frequent users among the respondents. Twitter $(\mathrm{M}=1.05)$ and Telegram $(1.03)$ were the least used of SM by the respondents. From these results, it could be induced that the used of SM were only limited to YouTube, WhatsApp and Facebook, indicating that pupils at elementary level were not widely exposed to a variety of SM. This result is similar to the past study which also attempted to explore the use SM for English learning (V. Li, 2017). This could possibly reflect students' preference of tools for English learning. This result could also be associated with their experience in using Internet. The shorter the people have exposed to the Internet, less time they spend and less activities they engage in on the web (Jiyoung Cha, 2010).

\subsection{Competency in Using SM and its Relationship with the Frequency of Using SM}

Table 4. Competency level in using Social Media (SM)

\begin{tabular}{cc}
\hline Social media & Mean score \\
\hline YouTube & 4.16 \\
Whatsapp & 3.43 \\
Facebook & 2.41 \\
Wechat & 2.24 \\
Tik Tok & 2.03 \\
Snapchat & 1.81 \\
Instagram & 1.76 \\
LINE & 1.57 \\
Twitter & 1.19 \\
Telegram & 1.16
\end{tabular}

Rating from 'very good' to 'not applicable' ranged from 1-5 (mid-point is 3)

Table 5. Correlation between frequency and competency level in using Social Media (SM)

\begin{tabular}{lrr}
\hline & Frequency & Competency level \\
\hline Frequency & 1 & $.998^{* *}$ \\
\hline Competency level & $.998^{* *}$ & 1
\end{tabular}


${ }^{* *}$ Correlation is significant at the 0.01 level (2-railed)

Based on the mean value in Table 4, YouTube and WhatsApp were the SM that pupils were good at using. In accordance to the previous result which revealed YouTube had the most frequent users, it is not strange that YouTube, with the mean value of 4.16, turned out to be the SM that was very well-mastered by most of the pupils. As YouTube was always used by most of the pupils, it was most likely that they were familiar with the features of the website. This was followed by WhatsApp, with the mean value of 3.43 also indicating their good competency level in WhatsApp. Facebook $(\mathrm{M}=2.41)$, which was ranked as the third SM that is often used, was moderately mastered by the pupils. As for Twitter and Telegram which were revealed as the least frequent user, the result in Table Twitter $(\mathrm{M}=1.19)$ and Telegram $(\mathrm{M}=1.16)$ are weak.

It was found that the frequency use of a social media tends to increase their competency level in using that social media. Results of the Pearson correlation in Table 5 indicated that there is a significant positive association between the frequency use of social media and competency level in using social media, $(\mathrm{r}(37)=.998, \mathrm{p}<.01)$. This result is in line with a study which found that the Internet experience is positively related to the frequency of the utilisation of social networking (Jiyoung Cha, 2010). The more hours they spend on using the SM, the higher their competency level in using it.

\subsection{Factors Affecting the Use of SM and Factors Contributing to the Use of SM across Gender}

Table 6. Distribution of factors

\begin{tabular}{|c|c|c|c|c|c|c|}
\hline \multirow{2}{*}{ Items } & \multicolumn{4}{|c|}{ Number of respondents (\%) } & \multirow[t]{2}{*}{ Mean score } & \multirow{2}{*}{$\begin{array}{c}\text { Mann- } \\
\text { Whitney Test } \\
\text { (Sig.) }\end{array}$} \\
\hline & SD & D & A & SA & & \\
\hline Fill my free time. & 5.4 & 32.4 & 43.2 & 18.9 & 3.30 & .061 \\
\hline $\begin{array}{l}\text { Follow the current trend (fashion, } \\
\text { movie, music). }\end{array}$ & 8.1 & 8.1 & 40.5 & 40.5 & 3.22 & .290 \\
\hline Communicate with my friends. & 10.8 & 13.5 & 32.4 & 40.5 & 3.11 & .748 \\
\hline Communicate with my family. & 10.8 & 13.5 & 32.4 & 40.5 & 3.11 & .843 \\
\hline Write on SM. & 16.2 & 10.8 & 51.4 & 21.6 & 2.78 & .453 \\
\hline Gain knowledge. & 5.4 & 32.4 & 43.2 & 18.9 & 2.76 & .915 \\
\hline Easy to use. & 10.8 & 24.3 & 43.2 & 21.6 & 2.76 & .112 \\
\hline Learn new things. & 13.5 & 21.6 & 43.2 & 21.6 & 2.73 & .453 \\
\hline Learn English. & 21.6 & 18.9 & 40.5 & 16.2 & 2.59 & .213 \\
\hline Share my ideas on SM. & 43.2 & 27.0 & 21.6 & 8.1 & 1.95 & .135 \\
\hline My friends use it. & 75.7 & 10.8 & 10.8 & 2.7 & 1.41 & .748 \\
\hline Do business. & 83.8 & 8.1 & 8.1 & 0 & 1.24 & .748 \\
\hline
\end{tabular}

Rating from 'strongly disagree' to 'strongly agree' ranged from $1-4$ (mid-point is 2.5 )

The factors from Table 6 can be explained and linked to the motive for using SM. The top factor contributing to the use of SM was 'passing time'. Most of the respondents $(M=3.30)$ strongly agreed that they use SM as they wanted to fill their free time. This associated with the study (Zolkepli \& Kamarulzaman, 2015) which revealed the passing time as one of the personal needs which could lead to greater participation in SM. Besides that, a great number of respondents $(M=3.22)$ strongly agreed that trendiness was one of the major factors of using SM. They used SM to fashion, movies and music which is regarded as entertainment motive for using SM (Jiyoung Cha, 2010; Papacharissi \& Rubin, 2000). Apart from that, social need was perceived to have a relatively strong influence. An equal number of pupils $(\mathrm{M}=3.11)$ strongly agreed that they embrace SM in order to stay connected with their friends and family. This is in line with the study shown in (Rdouan Faizi et al., 2014) that most of the students opt for social media to interact with their friends and family. Having interactivity experience through SM contributed a positive attitude towards the use of LMS in learning (Anderson \& Dron, 2017). In technology based writing classroom, pupils can use interactivity experience to interact with peers and teacher. Then, this is also related to the writing skill in the next finding with showed that more than half respondents $(M=2.78)$ were identified that they write on SM. Opposing to the finding in (Zolkepli \& Kamarulzaman, 2015), although social interaction is one of the major factor found in this study, the result in Table 6 revealed that the respondents' motive in using SM was scarcely socially influenced by people around them $(M=1.41)$.

Besides that, learning is also a relative important factors in using SM. Many of them agreed that they used SM to learn new things $(M=2.76)$, to gain knowledge $(M=2.73)$. This result could be because most of them are frequent users of YouTube. It has been found in the findings that YouTube users mostly seek information through viewing videos and reading comments (Muyingo, 2017). However, an information seeker would not typically disseminate or post videos (Khan, 2017). Therefore, a relatively less number of respondent $(M=1.95)$ claimed to do sharing on SM. As for convenience motive, slightly more than half pupils $(M=2.76)$ perceived SM as easy to use. It is believed that convenience motive was positively related to the frequency of SM use. The more frequent user of SM will find SM easier to be used.

As this study also aimed to investigate whether there was any significant factor contributing to the use of SM across gender, Mann-Whitney $U$ was carried out. The p significant results in Table 6 uncovered that there was no significant factor contributing to the use of SM between boys and girls. This is however, inconsistent to other findings (Gwena et al., 2018; Khan, 2017; Majid \& Stapa, 2017). 


\subsection{Use of English in Writing on SM}

\section{Table 7. Perception using English in writing on SM}

\begin{tabular}{lcc}
\hline \multicolumn{1}{c}{ Items } & Yes (\%) & No (\%) \\
\hline I prefer English when using SM. & 48.6 & 51.4 \\
I prefer to write in English on social media. & 40.5 & 59.5 \\
I feel confident to use English on social media with my friends. & 43.2 & 56.8 \\
I read what I have written to see if it is good before I post on SM (chat, comment, write & 54.1 & 45.9 \\
status). & 48.6 & 51.4 \\
I am aware of spelling when I write on social media (chat, comment, write status). & 32.4 & 67.6 \\
I am aware of punctuations when I write on social media (chat, comment, write status). & 24.3 & 75.7 \\
I ask my family or my friends to correct my mistakes before posting them on SM. & 48.6 & 51.4 \\
I ask someone for uncertain words or phrases when I write on SM (chat, comment, write & &
\end{tabular}

Based on Table 7, the result showed that the number of (48.6\%) pupils who preferred English is almost equal to the number of (51.4\%) pupils who did not. It is clearer that the use of English in writing was less prevailing among pupils even when they were on SM. There were more than half (59.5\%) pupils who did not prefer to write in English on SM. In relation to this, $(56.8 \%)$ pupils were not confident to utilise English to interact with their friend. This is consistent to the factors of anxieties and insecurities in writing (Alfian, 2017). As most of pupils were less confident to the use of English on SM, (54.1\%) pupils read what they had written to see if it was good before they posted it on SM. As stated in the result, there was an equal number of pupils (51.4\%) who was unconscious about spelling and they did not ask people around for help with uncertain words or phrases when they write on SM. As for punctuation, also, more than half of the pupils (67.6\%) perceived themselves as not being aware of punctuations in writing on SM. 75.7\% pupils would not ask their family or friends to correct their mistakes in writing. This large amount of pupils could have involved those pupils who do not write on SM. Referring to the demographic profile of this group of participants, most of the pupils' English proficiency are at intermediate and above-intermediate. This result can be generalised that most of the primary 4 pupils face the same problem towards writing. This result could be treated as the guideline for future researchers who attempt to use SM to teach writing skills on pupils of all English proficiency level at primary 4.

The overall results of the questionnaire showed that all the pupils have exposure and experience in using social media. Thus, it should be no problem for the educators to incorporate social media platform in learning writing among the primary 4 pupils in their school. YouTube appears to be the most prominent tool used among the pupils, followed by WhatsApp and Facebook. This could possibly reflect students' preference of tools for English learning. The educators should look into adopting the features from YouTube, Facebook and WhatsApp in choosing the right leaning writing platform for pupils so that the pupils can access to it and learn writing skill at ease (Tay \& Allen, 2011; Omar, Embi, Yunus, 2012). The reason that pupils engage themselves more often in using YouTube, WhatsApp and Facebook might be due to some of the factors that have been identified in this study. In fact, the factors could be categorized into academic and non-academic purposes. More than $80 \%$ of pupils engage in non-academic purposes such as to fill their free time by watching videos from YouTube or read the updates from various resources on Facebook, communicate with their family and friends through Facebook and WhatsApp. Although the results for academic purpose might not be as high as academic purposes, the results also revealed more than half pupils engage themselves in learning English as well as gaining knowledge through social media. The higher competency level in using YouTube, WhatsApp and Facebook could be due to the reason of ease of use of the tools, which is also one of the motive indicator in using social media (Papacharissi \& Rubin, 2000). All these can be concluded that the pupils have benefited themselves academically and non-academically by using social media (Khan, 2017). As for the perceptions of pupils towards the use of English in writing on social media, although the overall results are deviated towards negative perception, the number of negative responses are just slightly above half of the total number of participants. In other words, there are also nearly half of the pupils perceived positively towards writing using social media.

\section{CONCLUSION}

Taking these findings into account and in addition to the previous studies which have proven the effectiveness of social media in language learning, it is suggested that social media could be adapted and adopted as valuable education-al tools in language learning prior to modern technology prosperity. As far as the study concern with pupils' motives for using social media and its features of communicating, collaborating and contributing factor, pupils could write with confident, be more aware towards writing mechanism and thus perceive the impact of social media positively on their writing through some proper intervention using social media. In order for all the primary school pupils to be on par with learning using social media, there is a need to brush up competency level for using social media since some of them are not frequent user of social media and their experiences in using social media are different from each other. As social media is being rampantly used, it is important to educate pupils the risk of using this platform as such not to jeopardise their learning. The Ministry of Education in Malaysia should advocate the implementation of computer literacy course at primary education level so that pupils can make good use if it in potential learning. It is also suggested that the teaching and learning writing skills could either be conducted in fully online or in blended setting.

\section{ACKNOWLEDGMENT}

This research was supported by the grant from the Faculty of Education, Universiti Kebangsaan Malaysia (GG-2018001 and GG-2019-009). 


\section{BIBLIOGRAPHIC REFERENCES}

Abdullah, S. N. A., Hashim, H., \& Mahmud, M. S. (2018). Using Mobile Application as an Alternative to Pre-Writing Strategy. International Journal of Enginnering \& Technology, 7(4.21), 143-147.

Abdurahman, A. Z. A., Hassan, R. A., Sayuti, N. M., \& Abdullah, J. (2019). Social Network and Students: The Correlation Between Usage on Academic Performance and Non-academic Engagement. In Proceedings of the Regional Conference on Science, Technology and Social Sciences (RCSTSS 2016). https://doi.org/10.1007/978981-13-0203-9_10

Akhiar, A., Mydin, A. A., \& Kasuma, S. A. A. (2017). Students' perceptions and attitudes towards the use of Instagram in English language writing. Malaysian Journal of Learning and Instruction, (Special issue on Graduate Students Research on Education. pp. 47-72).

Alfian. (2017). The Utilization of Edmodo as Learning Strategy in Teaching Writing. 3(1), 1-15.

Anderson, T., \& Dron, J. (2017). Integrating learning management and social networking systems. Italian Journal of Educational Technology, 25(3), 5-19. https://doi.org/10.17471/2499-4324/950

Chaffey, D. (2019). Global social media research summary 2019 | Smart Insights. Retrieved August 23, 2019, from https://www.smartinsights.com/social-media-marketing/social-media-strategy/new-global-social-mediaresearch/

Chandran, Y., Plaindaren, C. J., Pavadai, S., \& Yunus, M. M. (2019). Collaborative Writing: An Integration of Snack Bars and Hi-Five Fingers via Social Media. Creative Education, 10(2), 475-484. https://doi.org/10.4236/ ce.2019.102034

El-Sawy, H. E. (2015). Students' Perceptions of Integrating Social Networking Sites in Language Learning: Benefits and Challenges. Journal of Research in Curriculum Instruction and Educational Technology, 1(2), 149-177. https:// doi.org/10.21608/jrciet.2015.24560

Faizi, R, Afia, A., \& Chiheb, R. (2013). Studentsé\#39; Perceptions on Social Media Use in Language Learning.

Faizi, Rdouan, El Afia, A., \& Chiheb, R. (2014). Social media: An optimal virtual environment for learning foreign languages. International Journal of Emerging Technologies in Learning, 9(5), 64-66. https://doi.org/10.3991/ ijet.v9i5.3911

Fauzi, A. (2017). The Effect of Edmodo on Students' Writing Skill in Recount Text. IJPTE: International Journal of Pedagogy and Teacher Education, 1(2). https://doi.org/10.20961/ijpte.v1i2.5038

Gwena, C., Chinyamurindi, W. T., \& Marange, C. (2018). Motives influencing Facebook usage as a social networking site: An empirical study using international students. Acta Commercii, 18(1). https://doi.org/10.4102/ ac.v18i1.521

Harmer, J. (2004). How to Teach Writing? Pearson Education Limited. UK: Edinburgh.

Harmer, J. (2007). How to Teach Writing? Pearson Education Limited. UK: Edinburgh.

Hashim, H., Yunus, M. M., Ibrahim, N. S. M., Jeri, E. J., SUKR, M. A. M., Ilahi, N. S. N., \& Nor Hassim, M. A. (2018). Social Media and Its Impact on Writing Skills. International Journal of Engineering \& Technology, 7(4.21), 102-106. https://doi.org/10.1542/PEDS.141.1_MEETINGABSTRACT.190-A

Jiyoung Cha. (2010). Factors affecting the frequency and amount of social networking site use: Motivations, perceptions, and privacy concerns. First Monday, 15(12).

Jumaat, N. F., Ahmad, N., Abu Samah, N., Ashari, Z. M., Ali, D. F., \& Abdullah, A. H. (2019). Facebook as a platform of social interactions for meaningful learning. International Journal of Emerging Technologies in Learning, 14(4), 151-159. https://doi.org/10.3991/ijet.v14.i04.9363

Khan, M. L. (2017). Social media engagement: What motivates user participation and consumption on YouTube? Computers in Human Behavior, 2017(66), 236-247. https://doi.org/10.1016/j.chb.2016.09.024

Lee, C. S., \& Ma, L. (2012). News sharing in social media: The effect of gratifications and prior experience. Computers in Human Behavior, 28(2), 331-339. https://doi.org/10.1016/j.chb.2011.10.002

Li, J., \& Greenhow, C. (2015). Scholars and social media: tweeting in the conference backchannel for professional learning. Educational Media International, 52(1), 1-14. https://doi.org/10.1080/09523987.2015.1005426

Li, V. (2017). Social Media in English Language Teaching and Learning. International Journal of Learning and Teaching, 3(1), 148-153. https://doi.org/10.18178/ijlt.3.2.148-153

Liu, L., Zhang, L., Ye, P., \& Liu, Q. (2018). Influencing factors of university students' use of social network sites: An empirical analysis in China. International Journal of Emerging Technologies in Learning, 13(3), 71-86. https:// doi.org/10.3991/ijet.v13i03.8380

Majid, A. H. A., \& Stapa, S. H. (2017). The use of scaffolding technique via Facebook in improving descriptive writing among ESL Learners. 3L: Language, Linguistics, Literature, 23(4), 77-88. https://doi. org/10.17576/3L-2017-2304-07

Mervat Abd Elfatah Ali Said Ahmed. (2016). Using Facebook to Develop Grammar Discussion and Writing Skills in English as a Foreign Language for University Students. Sino-US English Teaching, 13(12), 932-952. https:// doi.org/10.17265/1539-8072/2016.12.004

Mohammad, M., Ghazali, N., \& Hashim, H. (2018). Secondary school students' perceptions on the use of Google+ 
towards improving ESL writing skills. International Journal of Emerging Technologies in Learning, 13(9), 224 238. https://doi.org/10.3991/ijet.v13i09.8479

Mustapha, S. M., Rahman, N. S. N. A., \& Yunus, M. M. (2010a). Perceptions towards classroom participation: A Case Study of Malaysian Undergraduate Students. Procedia-Social and Behavioral Sciences, 7, 113-121. https://doi. org/10.1016/j.sbspro.2010.10.017

Mustapha, S. M., Rahman, N. S. N. A., \& Yunus, M. M. (2010b). Factors influencing classroom participation: A case study of Malaysian undergraduate students. Procedia - Social and Behavioral Sciences, 9(9), 1079-1084. https://dx.doi.org/10.1016/j.sbspro.2010.12.289

Muyingo, R. I. (2017). Usage and Gratification of Social Media in Higher Education: A Survey on the Perceptions of International Students in Turkey. Communication and Media Technologies, 7(3), 159-181.

Nordin, N. M., Hamzah, M. I., Yunus, M. M., \& Embi, M. A. (2010). The mobile learning environment for the inservice school administrators. Procedia - Social and Behavioral Sciences, 7(671-679).

Nov, O., Naaman, M., \& Ye, C. (2010). Analysis of participation in an online photo-sharing community: A multidimensional perspective. Journal of the American Society for Information Science and Technology, 61(3), 555-566. https://doi.org/10.1002/asi.21278

Novakovich, J. (2016). Fostering critical thinking and reflection through blog-mediated peer feedback. Journal of Computer Assisted Learning, 32(1), 16-30. https://doi.org/10.1111/jcal.12114

Obar, J. A., \& Wildman, S. (2015). Social media definition and the governance challenge: An introduction to the special issue. Telecommunications Policy, 39(9), 745-750. https://doi.org/10.1016/j.telpol.2015.07.014

Omar, H., Embi, M.A., Yunus, M.M. (2012). Learners' Use of Communication Strategies in an Online Discussion via Facebook. Procedia Sosial and Behavioral Sciences. 64 (535-544).mobile

Özad, B. E., \& Kutoglu, Ü. (2010). The use of the internet in media education. Turkish Online Journal of Educational Technology, 9(2), 245-255.

Papacharissi, Z., \& Rubin, A. M. (2000). Predictors of internet use. Journal of Broadcasting and Electronic Media, 44(2), 175-196. https://doi.org/10.1207/s15506878jobem4402_2

Rollinson, P. (2005). Using peer feedback in the ESL writing class. ELT Journal, 59(1), 23-30. https://doi.org/10.1093/ elt/cci003

Saad, N. S. M., Yunus, M. M., Embi, M. A., \& Mohd Yasin, M. S. (2014). Conducting online posting activity on a social networking site (SNS) to replace traditional learner diaries. In Cases on Critical and Qualitative Perspectives in Online Higher Education (pp. 489-508). https://doi.org/10.4018/978-1-4666-5051-0.ch025

Shabir, G., Yousef, M., Yousef, H., Safdar, G., Farouq, G. (2014). Impact of Social Media on Youth: A Case Study of Bahwalpur City. Asian Journal of Social Sciences and Humanities. https://doi.org/10.2501/IJMR-2014-000

Shiva, H. F., Fahimeh, J., \& Ghani, M. (2016). The relationship between the using of virtual social net. International Journal of Humanities and Cultural Studies, May (2016), 2426-2433.

Tay, E., \& Allen, M. (2011). Designing social media into university learning: Technology of collaboration or collaboration for technology? Educational Media International, 48(3), 151-163. https://doi.org/10.1080/09523987.2011.6 07319

Toetenel, L. (2014). Social networking: a collaborative open educational resource. Computer Assisted Language Learning, 27(2), 149-162. https://doi.org/10.1080/09588221.2013.818561

Won, S. G. L., Burton, J. K., Evans, M. A., Baum-Walker, L., \& Grafsky, E. (2015). Social Media as Connected Learning Technology: A Mixed Methods Investigation of Facebook for Undergraduate Education.

Yunus, M., Hasim, H., Embi, M. A. \& Lubis, M. A. (2010). The Utilization of ICT in the Teaching and Learning of English: 'Tell Me More'. Procedia. Social and Behavioural Sciences, 9, 685-691. https://doi.org/10.1016/j. sbspro.2010.12.218

Yusof, J., Manan, N. A. A., \& Alias, A. A. (2012). Guided Peer Feedback on Academic Writing Tasks using Facebook Notes: An Exploratory Study. Procedia - Social and Behavioral Sciences, 2012(67), 216-228. https://doi. org/10.1016/j.sbspro.2012.11.324

Zolkepli, I. A., \& Kamarulzaman, Y. (2015). Social media adoption: The role of media needs and innovation characteristics. Computers in Human Behavior, 2015(43), 189-209. https://doi.org/10.1016/j.chb.2014.10.050 